\title{
Short Communication: Seed germination of twelve Indonesian begonias for conservation
}

\author{
MUHAMMAD EFENDI", AISYAH HANDAYANI, INTANI QUARTA LAILATY \\ Cibodas Botanic Gardens, Indonesian Institutes of Sciences. Jl. Kebun Raya Cibodas, Sindangjaya, Cipanas, Cianjur 43253, West Java, Indonesia. \\ Tel./fax.: +62-263-512233, `email: muhammadefendi05@gmail.com
}

Manuscript received: 7 December 2018. Revision accepted: 29 March 2019.

\begin{abstract}
Efendi M, Handayani A, Lailaty IQ. 2019. Short Communication: Seed germination of twelve Indonesian begonias for conservation. Biodiversitas 20: 1192-1197. Knowledge of seed quality is essential when seeds are stored for the long term. A preliminary study on Begonia seed conservation was conducted, to characterize morphology and germination testing on native Begonia from Indonesia. As many as 12 species of Indonesian Begonia were observed for the characteristics of fruit and seeds. Later, we tested the level of seed viability at different levels of fruit maturity. The experimental design used a Completely Randomized Design (CRD) with two factors. Data analysis was performed using the Statistical Tool for Agricultural Research (STAR) program and further testing the Duncan Multiple Range Test (DMRT) at a 5\% significance level. Generally, all seeds were barrel-like in shape, the smallest size in $B$. muricata (252.42 $\mu \mathrm{m}$ length), and the largest size in $B$. areolata (up to $451.42 \mu \mathrm{m}$ length, while the operculum $28.48 \mu \mathrm{m}-104.9 \mu \mathrm{m}$ length). Most Begonia seeds start germinating in the second and third weeks after sowing. B. scottii, and B. verecunda, as well as B. longifolia, showed germination in the second week, while other species tended not to be simultaneous. Dry seed germination was higher than seed wet for eight weeks. B. longifolia and B. scottii had the highest germination in wet seed treatment: while in the dry seed treatment, the highest germination was showed by B. areolata and B. muricata.
\end{abstract}

Keywords: After ripening, Begonia, dormancy, ex situ conservation, germination, seed

\section{INTRODUCTION}

Cibodas Botanical Garden, an ex situ conservation site for tropical mountain flora, provides genetic resources from their natural habitat in Indonesia. Unfortunately, the main problem with ex situ conservation is having a limited area, so only species samples are collected. Therefore, it is necessary to optimize species collection strategies to accommodate high species diversities and genetic resources. Seed banks can conserve larger collections.

This type of collection also increases the representation of high genetic diversity. Small amounts of seeds can be stored in bottles so that it is possible to accommodate a more significant collection. For example, Begonia seeds are microscopic, ranging from 200 to $600 \mu \mathrm{m}$ in length (Doorenbos et al. 1998). According to Haba (2015), Begonia seeds without endosperms and with embryos are difficult to distinguish. Anatomical studies of seed germination and seedling development provide more details about the germination process. Mature seeds consist of testa, one endosperm cell layer, two well-developed cotyledons, and a very small apical meristem.

Information on the physiological characteristics of Begonia seeds, especially the native Begonia of Indonesia, are little known. On the other hand, the management of germplasm through seeds presents a challenge to ensure that the seeds are high quality, viable, and have a long shelf life. Seed dormancy, due to morphological, physical, and physiological characteristics, such as immature embryos, also affects the viability and vigor of seeds.
In general, Indonesian Begonia has a capsule fruit type, i.e., dried fruit when old, except the Sphenanthera section, (now considered Platycentrum section by Moonlight et al. 2018) with fleshy fruit. Information on the maturity level of seeds for both types of Begonia needs to be known to determine the optimal harvest time, so the seeds with high germination rate can be obtained. Besides, Begonia has a wide distribution in high environmental diversity, so the seed germination rate and seed germination response in each type of Begonia are different (Haba 2015). In this study, we tested the level of seed viability of twelve species of Begonia at varying levels of fruit maturity, and recorded the morphological characters of fruit and seeds to complete the description of existing Begonia species.

\section{MATERIALS AND METHODS}

\section{Time and research site}

The study was conducted from April to September 2018, in the Laboratory of Cibodas Botanical Garden, West Java. The laboratory has a temperature of 19 to $22^{\circ} \mathrm{C}$ and humidity of 74 to $83 \%$. This is similar to the optimum germination environment according to Haba (2015).

A total of 12 Begonia species collected from Mt. Ketambe Leuser National Park, Mt. Slamet, and remnant forest of Cibodas Botanical Garden and from the living collection in Cibodas Botanical Garden and Bogor Botanical Garden were used in this study (Table 1). The ripe fruit was harvested and dried at room temperature. The 
drying time depended on the fruit type. The capsule type was dried for 2-4 days at room temperature, while fleshy fruit or berry-like were dried for 2-3 weeks also at room temperature. Then, seeds were separated from their fruit coat. Seeds were sown on filter paper in a petri dish and moistened with AquaDes.

The experimental treatment was based on differences in the level of fruit maturity using a completely randomized design (CRD) with two factors, i.e seed condition (wet and dry seed) and species of Begonia. Each petri dish had 50 seeds, and each treatment consisted of three replications. Germination parameters including germination type, number of seeds germinating and germination time. Observation of seed germination was carried out for eight weeks, with an observation time of 6 to 8 days.

The fruit and seed were characterized using some characters referred to by Doorenbos et al. (1998). Measurement of seed length and width, a well as operculum length were observed using OptiLab® microscope. Observation of the germination phase of each seed was also examined every 3 to 4 days until the seed achieved complete germination, using OptiLab® microscope.

\section{Data analysis}

The germination data were analyzed using the descriptive method and analysis of variance with the $\mathrm{F}$ test at $5 \%$ significance level. If, the $\mathrm{F}$ test has a significant effect, further testing of the middle value was undertaken with Duncan's multiple range test (Duncan Multiple Range Test/DMRT) at 5\% significance level. The software used was Microsoft Excel ${ }^{\circledR}$ and the Statistical Tool for Agricultural Research (STAR 2.0.1).

\section{RESULTS AND DISCUSSION}

\section{Morphological of fruit and seeds of Begonia}

Twelve Begonia species belonging to four sections, have been described based on fruit and seed character. Comparisons of fruits and seeds morphology are presented in Table 1. Begonia longifolia, B. scottii and B. multangula are fleshy fruit, while the others are dried capsule type. The fruit types and their sizes can be related to seed dispersal in their natural habitat. The capsule types are mostly dispersed by water and wind, and fleshy fruit Begonia are dispersed by animals (Tebbitt 2005; Rajbhandary and Shrestha 2010).

Some Begonias have a different pattern for pollination. Begonia sect. Petermannia, (B. laruei, B. isoptera, and B. hooveriana) have many female flowers but are less productive than male flowers and may open first before male flowers. On the other hand, male flowers that open earlier than female flowers, known as protandrous types, occur in B. areolata, B. leuserensis, and Begonia sect. Jackia. This condition forces cross-pollination between plants (Kiew 2005). In some species, for example, $B$. multangula, B. longifolia and B. scottii, the female and male flower blooming simultaneously, so that more pollination results in inbreeding.
Morphologically, Begonia seeds are barrel-like, with the bodies ovate, obovate, oblate or pointed. Their size ranged from $252.42 \mu \mathrm{m}$ to $451.25 \mu \mathrm{m}$ length, $160.06 \mu \mathrm{m}$ to $284.83 \mu \mathrm{m}$ width. The biggest size of Begonia seed was $B$. areolata, while $B$. muricata is smallest. These data add morphological descriptions to previous studies (Hughes et al. 2009; Wiriadinata 2013; Hughes et al. 2017). Commonly, the mature seed is brown to dark brown and yellowish brown when still young. The drying process causes the seed to turn brown or darker brown.

\section{Begonias seed germination process}

Begonia is considered to have seeds without endosperms or only with a little endosperm (Tebbitt and Garden 2005; Haba 2015). Furthermore, the embryo in the germination of Begonia seeds filled all the inside of the fully developed seed shell according to $\mathrm{Hu}$ et al. (2012) used X-ray exposure.

Two Begonia species, i.e. B. muricata (capsule type) and $B$. scottii (fleshy type) were used as a model, while other germinations are not displayed in this paper. Seeds germination was started by an imbibition process, the seeds take up water and were more prominent and shiny. Furthermore, the operculum opening involves hypocotyl elongation and root hair production at the base of the hypocotyls. Two foliaceous cotyledons, which are encased in a seed coat, grow from the hypocotyl tip. Roots appeared under the collet when cotyledons have developed, followed by elongation of the radicle and root development (Figure 2 ). This process is similar to the germination pattern on $B$. fischeri (Haba 2015).

The germination phase of Begonia seeds is unique compared to common dicotyledonous seeds. Usually, the germination of the dicotyledonous phase includes imbibition, testa or seed coat rupture, the appearance of the radicle, followed by hypocotyl and epicotyl elongation until the leaves appear (de Vogel 1980), while in Begonia, radicles emergence after the hypocotyl elongation stage.

\section{The effect of fruit maturity level on seed germination of Begonia}

From 12 Begonia species tested for germination, 8 species (B.aerolata, B.hooveriana, B.isoptera, B.kudoensis, B.laruei, B.muricata, B.scotii, and B.sudjanae) were tested using dry seeds and wet seeds, while three of them (B.longifolia, B.multangula, and B.verecunda) are only wet seeds, and B.leuserensis is only dry seeds. This is due to limited seeds obtained from the four types of these Begonia.

Time and percentage of seed germination from 12 species of Begonia have been recorded. Generally, seed germination begins at the first to fourth week after sowing (Figure 3). Begonia hooveriana was the only species known to germinate in first week. Begonia scottii, $B$. areolata, B. leuserensis, B. verecunda, B. longifolia, and $B$. multangula were germinating in second week, while $B$. laruei, B. kudoensis, B. sudjanae and B. muricata were germinating in third week, and the last germinating in fourth week is Begonia isoptera. 
Table 1. The morphological comparison on fruit and seed of 12 species Begonia

\begin{tabular}{|c|c|c|c|c|c|c|c|c|c|c|}
\hline \multirow[b]{2}{*}{ No Species } & \multirow[b]{2}{*}{ Origin } & \multicolumn{2}{|c|}{ Fruit } & \multirow{2}{*}{$\begin{array}{c}\text { Locule } \\
\text { number }\end{array}$} & \multicolumn{3}{|r|}{ Wings } & \multicolumn{2}{|c|}{ Seed } & \multirow{2}{*}{$\begin{array}{c}\text { Operculum } \\
\text { length } \\
(\mu \mathrm{m})\end{array}$} \\
\hline & & Type & $\begin{array}{c}\text { Length } \\
(\mathrm{cm})\end{array}$ & & Shape & equal & $\begin{array}{l}\text { Sizes } \\
(\mathbf{c m})\end{array}$ & $\begin{array}{c}\text { Length } \\
(\mu \mathrm{m})\end{array}$ & $\begin{array}{c}\text { Width } \\
(\mu \mathrm{m})\end{array}$ & \\
\hline \multicolumn{11}{|l|}{ Sect. Platycentrum } \\
\hline B. areolata & Mt. Slamet & Capsule & up to 1.8 & 2 & Hook-like & Anequal & 1.3 to 1.8 ; other 0.4 to 1.0 & Barrel $342.60-451.25$ & $179.71-284.83$ & $37.26-104.9$ \\
\hline B. leuserensis & Mt. Ketambe & Capsule & up to 2.0 & 2 & Hook-like & Unequal & up to $20 ;$ other 0.7 & Barrel 283.50-414.80 & $211.3-276.45$ & $28.63-78.4$ \\
\hline B. longifolia & Remnant forest of CBC & Fleshy & up to 2.0 & 3 & Curved & Equal & up to 0.3 & Barrel 284.47-306.99 & $184.38-208.85$ & $29.27-56.38$ \\
\hline B. multangula & Remnant forest of CBC & Fleshy & up to 2.5 & 3 & Curved & subequal & up to 3.0 & Barrel $304.81-356.54$ & $173.37-224.16$ & $28.48-72.06$ \\
\hline B. scottii & Mt. Pesagi & Fleshy & up to 2.1 & 3 & Rounded & subequal & up to 1 & Barrel 330.69-425.66 & $166.44-256.72$ & $28.97-73.3$ \\
\hline \multicolumn{11}{|l|}{ Sect. Petermannia } \\
\hline B. hooveriana & BBG collection & Capsule & up to 3.0 & 3 & Curved & Equal & up to 2 & Barrel 329.60-389.10 & $182.61-220.31$ & $33.75-66.08$ \\
\hline B. isoptera & Remnant forest of CBC & Capsule & up to 3.0 & 3 & Bell-like & equal & 3.0 & Barrel 292.64-354.35 & $184.06-238.91$ & $29.99-62.96$ \\
\hline B. laruei & Mt. Ketambe & Capsule & up to 2.5 & 3 & Rounded & equal & 3.0 & Barrel $298.82-379.16$ & $187.04-243.66$ & $35.4-83.95$ \\
\hline \multicolumn{11}{|l|}{ Sect. Jackia } \\
\hline B. kudoenis & BBG collection & Capsule & up to 1.5 & 3 & Curved & Equal & 0.9 to 1.2 & Barrel $368.98-438.48$ & $228.16-271.15$ & $54.28-90.48$ \\
\hline B. muricata & Mt. Slamet & Capsule & up to 1.0 & 3 & Rounded & equal & 0.3 to 0.5 & Barrel 252.42-292.97 & $160.06-197.49$ & 29.23-71.75 \\
\hline B. sudjanae & BBG collection & Capsule & up to 0.8 & 3 & Curved & subequal & 0.5 to 0.8 & Barrel $318.53-379.63$ & $186.93-226.04$ & $27.41-62.72$ \\
\hline ct. Bracteibegor & & & & & & & & & & \\
\hline B. verecunda & Mt. Ketambe & Capsule & up to 1.0 & 3 & Curved & subequal & 0.2 to 0.4 & Barrel 269.95-316.42 & $165.54-215.53$ & $36.66-60.05$ \\
\hline
\end{tabular}

Notes: $\mathrm{CBG}=$ Cibodas Botanical Garden; $\mathrm{BBG}=$ Bogor Botanical Garden 

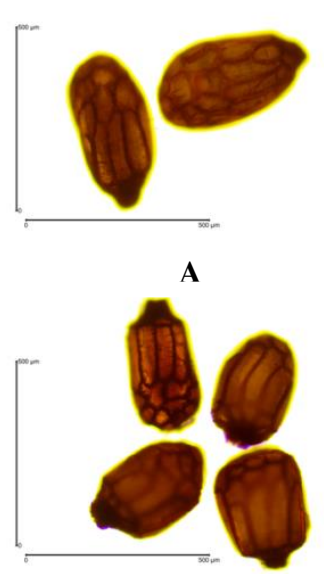

F.

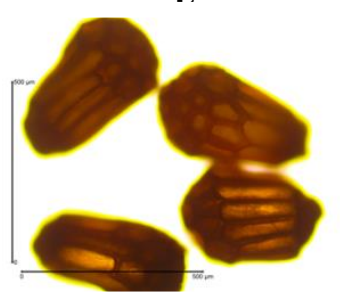

I

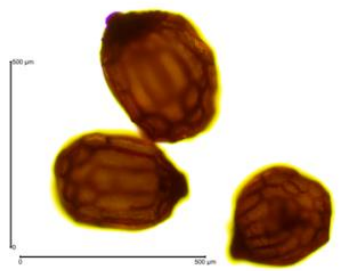

B

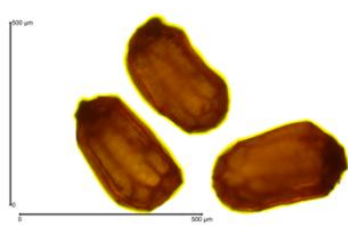

$\mathbf{F}$

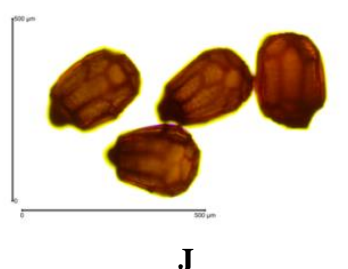

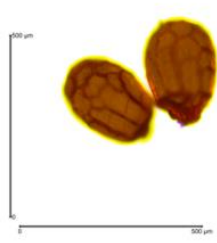

C

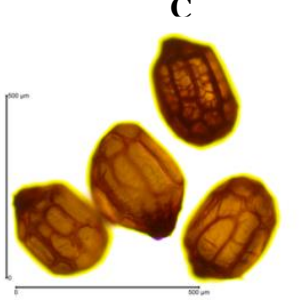

G

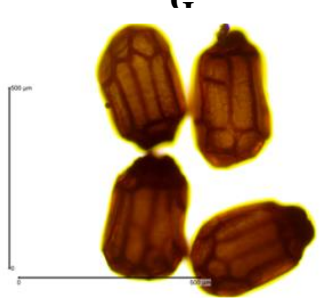

K

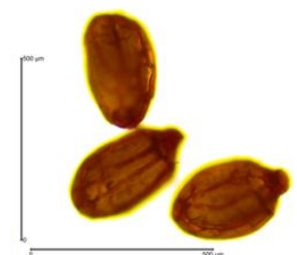

D

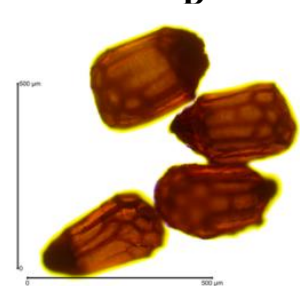

H

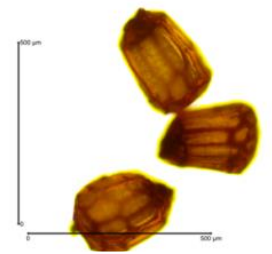

L

Figure 1. A. Seeds of Begonia areolata Miq. § Platycentrum, B. Begonia leuserensis Hughes $\S$ Platycentrum C. Begonia longifolia B1. $\S$ Platycentrum, D. Begonia multangula Bl. § Platycentrum, E. Begonia scottii Tebbitt. § Platycentrum, F. Begonia hooveriana Wiriad. $\S$ Petermannia, G. Begonia isoptera Dryand. ex. Sm. § Petermannia, H. Begonia laruei Hughes. § Petermannia, I. Begonia kudoensis Girm. § Jackia, J. Begonia muricata B1. § Jackia, K. Begonia sudjanae Janson $\S$ Jackia, L. Begonia verecunda Hughes § Bracteibegonia with 200x magnification (Bar=500 $\mu \mathrm{m})$.
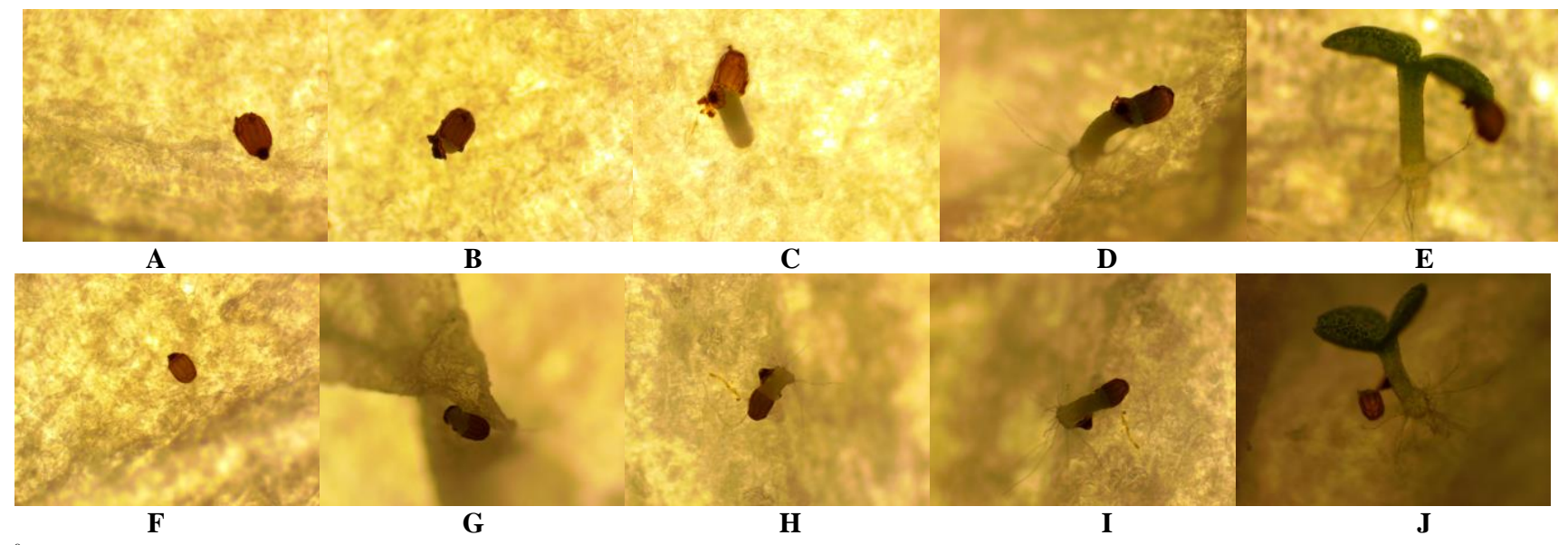

Figure 2. Seed germination phase of Begonia scottii (A-E) and B. muricata (F-J). A, F: imbibitions process, B, G: operculum opening, C, H: hypocotyl elongation, D, I: root hair production on hypocotyls base, E, J: Cotyledons opened (Images are taken by 40x magnification)

Seed germination of B. scottii co-occurred in the second week, both in wet and dry fruit. This phenomenon also occurred in wet seed B. Longifolia and B.multangula. Begonia scottii, B. longifolia, B. multangula, are classified as fleshy fruit Begonia, and it is difficult to differentiate between young and old fruit. This factor causes a low germination rate in B.multangula because the fruit's maturity level is unknown.

Another type of fruit, capsule fruit type, consists of nine types i.e B.aerolata, B. hooveriana, B. isopteran, B.kudoensis, B.laruei, B.muricata, B.sudjanae, B. verecunda, and $B$. leuserensis has various time of germination, from two weeks to four weeks after sowing. 
The difference in the number of seeds that germinate on this type of fruit is quite obvious. In six Begonia species using dry seeds and wet seeds, the number of dried seeds germinated more than wet seeds, except for B.laruei which was almost the same amount. In the remaining two types, namely B. verecunda, and B.leuserensis which only use dry seeds, it can be seen that the germination time starts from the second week with the number of seeds germinating reaching 60-70\%.

Seed from wet capsule fruit produced lower germination and un-uniform emergence, than dried fruit, perhaps due to the variability of embryo immature and its unreadiness to germinate (Rajjou et al. 2012). This causes on capsule fruit type dried fruit conditions are a requirement for producing high-germination seeds, i.e $B$. areolata, B. hooveriana, B. isoptera, B. kudoensis, B. muricata, and B. sudjanae (Figure 3). In other cases, there is primary dormancy in the seeds due to physiologically immature embryos. Seed drying is the process of breaking seed dormancy (after-ripening), so the seeds can mature through its metabolism, like as in Carica papaya (Sebayang et al. 2014).
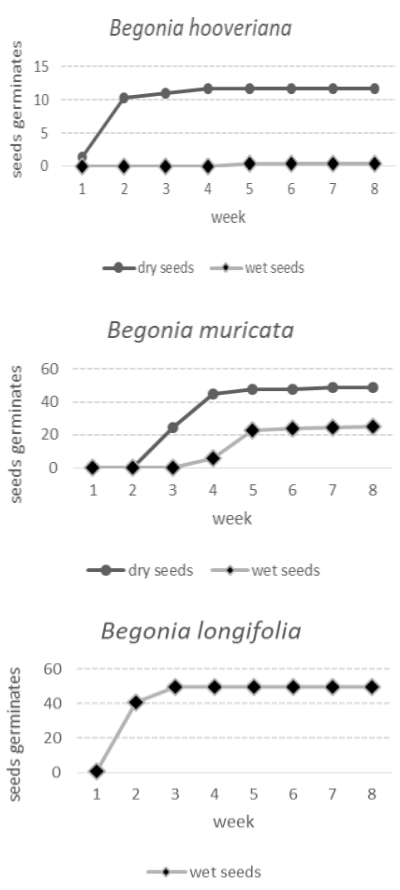
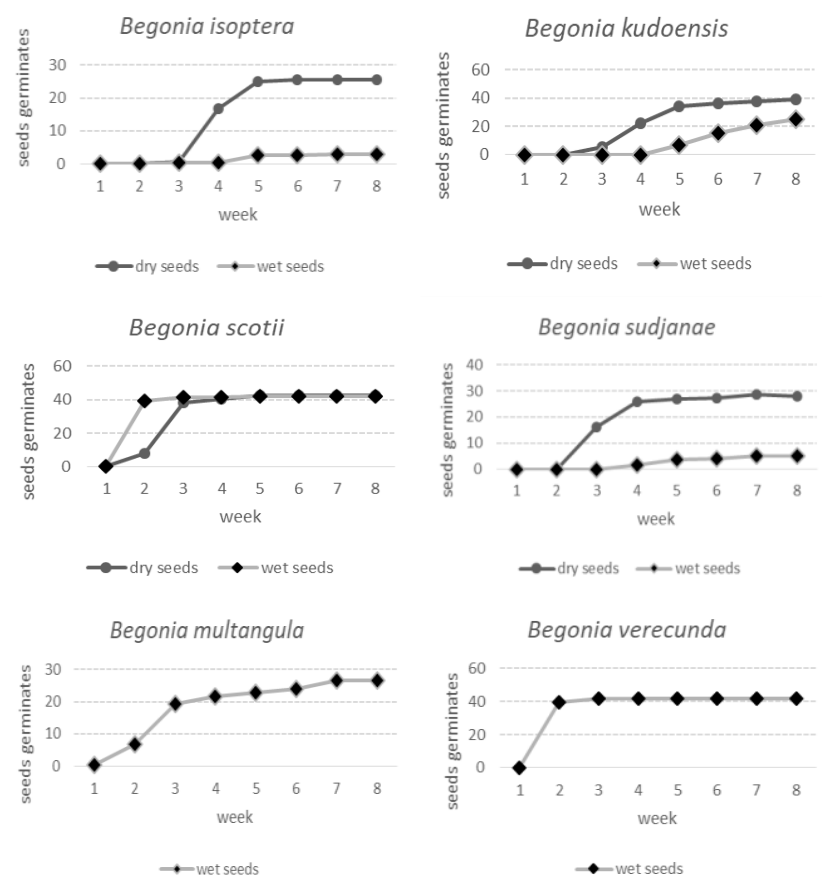
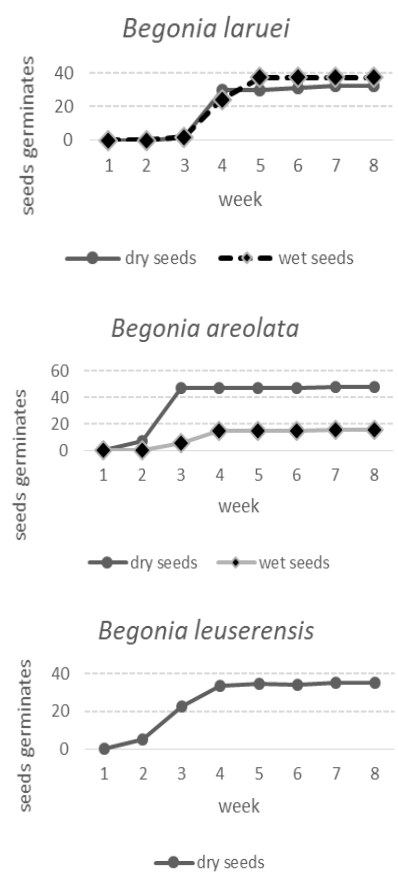

Figure 3. The graphic of seed germination number (y axis) of 12 species Begonia for 8 weeks after sowing (x axis)

Table 2. Germination rate of twelve species Begonia in wet and dried seeds treatment

\begin{tabular}{lll}
\hline Species & Wet seeds $(\%)$ & Dried seeds $(\%)$ \\
\hline Begonia areolata & $30.67 \mathrm{~cd}$ & $95.33 \mathrm{a}$ \\
B. hooveriana & $0.40 \mathrm{e}$ & $23.33 \mathrm{~d}$ \\
B. isoptera & $6.00 \mathrm{de}$ & $51.33 \mathrm{c}$ \\
B. kudoensis & $50.00 \mathrm{bc}$ & $78.00 \mathrm{abc}$ \\
B. laruei & $74.67 \mathrm{ab}$ & $64.67 \mathrm{bc}$ \\
B. leuserensis & - & $70.00 \mathrm{abc}$ \\
B. longifolia & $99.60 \mathrm{a}$ & - \\
B. multangula & $53.33 \mathrm{bc}$ & - \\
B. muricata & $50.00 \mathrm{bc}$ & $96.80 \mathrm{a}$ \\
B. scottii & $90.40 \mathrm{a}$ & $85.33 \mathrm{ab}$ \\
B. sudjanae & $10.00 \mathrm{de}$ & $56.00 \mathrm{bc}$ \\
B. verecunda & - & $60.00 \mathrm{bc}$ \\
\hline Net & &
\end{tabular}

Notes: The numbers followed by the same letter for each column are not different in the Duncan Multiple Range Test (DMRT) at a significance level of $5 \%$.
After eight weeks of observation, it showed that there was a significant difference of seed germination among wet and dried seed treatment in capsule fruit Begonia: $B$. areolata, B. hooveriana, B. isoptera, B. kudoensis, B. muricata and $B$. sudjanae. In an immature seed, embryo and other components for germinating are not yet available, so the seed vigor is low or delayed emergence (Kartika and Ilyas 1994; Normasiwi 2013; Wulanganggraeni et al. 2016). Thus, delay harvesting until dried fruit and mature is highly recommended for this group. However, B. scottii, a fleshy fruit group, showed no significant difference, both in wet and dried fruit treatment. So, a few late harvesting in this type can still be tolerated.

Mature seeds showed a higher germination rate and also produced plants that grow faster. Genotypic differences are also a significant source of variation for germination and flowering response. Increased proportions of germination 
through the after-ripening process are common in seeds with physiological dormancy and have been interpreted as a mechanism to ensure that seeds do not germinate after dispersing, even under favorable conditions (Finch-Savage and Leubner-Metzger 2006).

Finally, it is necessary to pay attention of post-harvest handling to ensure the quality of stored seeds. In addition, from the research that has been done, it is known that there is a risk of seed fail to germinate if harvesting young fruit, especially in capsule fruit Begonia type.The dry fruit: the condition is ripe, will produce the highest germination. On the other hand, the dry fruit of fleshy fruit Begonia, B.scotii, showed a decreasing seed germination number although not significantly different. Thus, for seed storage of Begonia it is recommended to use seeds from ripe fruit: dried for capsule fruit Begonia and dried or wet for fleshyfruit Begonia.

\section{ACKNOWLEDGEMENTS}

The authors are grateful to Taufiqurrahman Nasution from Cibodas Botanical Garden and Wisnu H. Ardi from Bogor Botanical Garden, who have provided the seed Begonias. We also thanks to Stephen Maciejewski and Michael LoFurno, the USA for editorial assistance.

\section{REFERENCES}

Bentsink L, Koornneef M. 2008. Seed Dormancy and Germination. The Arabidopsis Book. American Society of Plant Biologists. DOL: 10.1199/tab.0119 pp 1 of 18-18.

Carrera E, Holman T, Medhurst A, Dietrich D, Footitt S, Theodoulou FL, Holdsworth MJ. 2008. Seed after-ripening is a discrete developmental pathway associated with specific gene networks in Arbidopsis. Plant J 53 (2): 214-224.

Doorenbos J, Sosef MSM, de Wilde JJPE. 1998. The sections of Begonia including descriptions, keys, and species list. Studies in Begoniaceae VI. Wageningen Agricultural University, Netherland.

Finch-Savage W, Leubner-Metzger G. 2006. Seed dormancy and the control of germination. New Phytol 171: 501-523.
Haba SR. 2015. Conservation of Begonia Germplasm through Seeds: Characterization of Germination and Vigor in Different Species. [Thesis]. Graduate Program in Horticulture and Crop Science, Ohio State University, Columbus, $\mathrm{OH}$.

Hu XJ, Yang LH, Guan KY. 2012. Physiological dormancy in seeds of two endemic species of Begonia from Yunnan Province, China: diagnosis and classification. Plant Species Biol. DOI: 10.1111/j.14421984.2011.00344.x

Hughes M, Girmansyah D, Ardi WH, Nurainas. 2009. Seven new species of Begonia from Sumatra. Gard Bull Sing 61 (1): 29-44.

Hughes M, Girmansyah D, Ardi WH. 2017. Further discoveries in the ever-expanding genus Begonia (Begoniaceae): fifteen new species from Sumatra. European J Taxon 167: 1-40.

Kartika E, Ilyas E. 1994. Pengaruh tingkat kemasakan benih dan metode konservasi terhadap vigor benih dan vigor kacang jogo (Phaseolus vulgaris L.). Bul Agronomi 22 (2): 44-59. [Indonesian]

Moonlight PW, Ardi WH, Padilla LA, Kuo-Fang C, Fuller D, Girmansyah D, Hollands R, Jara-Muñoz A, Kiew R, Wai-Chao L, Liu Y, Mahardika A, Marasinghe LDK, O'Connor M, Peng CI, Pérez AJ, Phutthai T, Pullan M, Rajbhandary S, Reynel C, Rubite RR, Sang J, Scherberich D, Shui YM, Tebbitt MC, Thomas DC, Wilson HP, Zaini NH, Hughes M. 2018. Dividing and conquering the fastest-growing genus: Towards a natural sectional classification of the mega-diverse genus Begonia (Begoniaceae). Taxon 67 (2): 267-323.

Tebbitt MC. 2005. Begonias: Cultivation, Identfication, and Natural History. Timber Press, Portland, OR.

Normasiwi S. 2013. Tingkat kematangan buah dan pengaruhnya terhadap perkecambahan Ardisia spp. Prosiding Ekspose Pembangunan Kebun Raya dan Seminar Konservasi Flora Indonesia: Membangun Kebun Raya untuk Penyelamatan Keanekaragaman Hayati dan Lingkungan Menuju Ekonomi Hijau. Pusat Konservasi Tumbuhan Kebun Raya Bogor-LIPI, Bogor, 25-26 November 2013. [Indonesian]

Rajbhandary S, Shrestha KK. 2010. Taxonomic and ecological significance of seed micromorphology in Himalayan Begonias: SEM analysis. Pak J Bot 42: 135-154.

Rajjou L, Duval M, Gallardo K, Catusse J, Bally J, Job C, Job D. 2012. Seed Germination and vigor. Ann Rev Plant Biol 63: 507-33

Relf D. 2015. Plant Propagation from Seed. Virginia Polytechnic Institute and State University, USA.

Sebayang A, Nissa TC, Rahmawati N. 2014. Influence of ripeness, seed drying and seed skin condition on the germination of papaya seeds (Carica papaya L.) variety callina. Jurnal Online Agroekoteknologi 2 (3): 1133-1141

Wiriadinata H. 2013. A new species of Begonia (Begoniaceae) from South Sulawesi, Indonesia. Reinwardtia 13 (5): 445-448.

Wulanganggraeni R, Damanhuri, Purnamaningsih SL. 2016. Pengaruh perbedaan tingkat kemasakan buah pada 3 genotip mentimun (Cucumis sativus L.) terhadap kualitas benih. Jurnal Produksi Tanaman 4 (5): 332-341. [Indonesian] 